\title{
Implementation of Fuzzy Logic Technique in a Decision Support Tool: Basis for Choosing Appropriate Career Path
}

\author{
Benilda Eleonor V. Comendador, Wilmarie Faye C. Becbec, and John Rez P. de Guzman
}

\begin{abstract}
The authors implemented a fuzzy logic technique to develop a mobile based decision support tool called Generalized STEM-College Aptitude Test (GSTEM-CAT). It is an application that can recommend to the college applicant what appropriate university program can be enrolled based on ones' personality type and knowledge strength. Moreover, the students may enjoy GSTEM-CAT application because they see graphical objects associated to personality type test. The developed tool was evaluated by the respondents and based on the evaluation results, the software satisfied its implied functions and is functional, usable and reliable. Hence, it can be already used by the students and school administrators to assess and recommend set of college program that the student may take up, therefore providing opportunities for successful program completion.
\end{abstract}

Index Terms-Decision support tool, fuzzy control system, fuzzy logic technique, holland's code.

\section{INTRODUCTION}

Implementation of the K-12 Program as the new and enhanced basic education among schools and universities in the Philippines is still on its infancy [1]. In the government's plan to persistently hone individuals' character, the enhanced basic education offers core subjects for further skills development. Science, Technology, Engineering and Mathematics (STEM) strand under the academic track of Senior High School (SHS) is the most advisable yet challenging to those who want to pursue further studies in college [2]. With STEM track's ideal completeness and with it having multiple field of studies in focus, possible choices of college course, essentially with degree and career opportunities for graduates are extremely abundant. However, a mismatch between an individual's academic achievements, personality, interest and abilities in choosing a career path are potentially caused by lack of proper advice from suitable professionals or university services. Consequently, the wrong career choice or the inappropriate career choice affects the future of the students as well as the development of the nation

Manuscript received August 11, 2019; revised January 5, 2020. This work was supported in part by the Polytechnic University of the Philippines.

The authors are with the Polytechnic University of the Philippines, College of Computer and Information Sciences, Sta. Mesa, Manila, Philippines (e-mail: bennycomendador@yahoo.com, johnrezdeguzman9123@gmail.com).
[3].

Conversely, Information Communication Technology (ICT) causes a significant impact on pedagogy and using ICT technologies in school-related activities [4] and [5]. It is considered as a powerful tool which may provide educational opportunities in both formal and non-formal ways. For instance, Dela Rosa emphasized that in the teaching-learning process, ICTs can increase learners' motivation and engagement in classroom learning [6]. On the other hand, Ahmad developed a decision support tool for academic advising using personal information and academic record as factors for the resulting outputs [7]. Developing a Decision Support tool for SHS may provide an assistance and supports problem solving with the help of available data and models in a certain domain. In this light, the human queries the application to get help in taking decisions but not to the extent that the tool replace a human's decision making ability and take the final decision [8].

Fuzzy logic in a decision support system seems to be the most applicable method to use for it gives an imprecise or degreed values basis for the decision-making process. In addition, computer science researchers [9], [10] and other field innovators choose this approach among wide variety of methods. Study showed that the use of recommender systems without a guide or controller may result in a confusing and inaccurate results. With fuzzy logic technique, the data and knowledge inferencing will result in a much ideal outcome [11]. Many decision making and problem solving tasks are too complex to be understood quantitatively, however, people succeed by using knowledge that is imprecise rather than precise. The model used for a fuzzy control system is composed of three major components. These are: 1.) the set of input membership functions, 2.) a rule-based controller and 3.) a defuzzification process. If there will be a number of inputs in the fuzzy system, each of these inputs can have several membership functions. Using membership functions, each of the inputs will have corresponding weight or degree of membership in the output of the system [12].

Hence, implementing the fuzzy logic approach on the educational system lead to enhance the evaluation techniques of students so that better results can be obtained. Apparently, little research has been conducted that can be utilized by the Senior High School students for choosing appropriate career path. Thus, this study focused on providing a mobile based tool using fuzzy logic approach that can be utilized by students which may encourage students in understanding himself and facilitating program selection effectively through interaction. Specifically, it addressed the following sub-problems: 1.) what are the challenges encountered by the 
respondents in choosing their college programs; 2.) what are the appropriate features of the software that can be developed to address the challenges encountered; 3.) what is the level of acceptance of the respondents with the developed system in terms of: a.) functionality; b.) usability; and c.) reliability.

\section{RESEARCH Method AND TECHNIQUES}

The researchers developed an interactive module utilizing fuzzy logic approach for senior High School Students. Prior to the software development, the researchers conducted an informational interview with the Student Council Adviser and let the adviser checked the contents of the STEM based knowledge test items embedded in the developed system then validated the rules in the inference engine. The adviser personally deliberated and disclosed to the researchers a few points which should be considered of most extreme significance. The suggestions given by the adviser served as the basis for further updates and enhancement of the tool. Meanwhile, to evaluate the data generated by the tool in terms of its accuracy and performance the researchers conducted and developed an experiment paper for this purpose. Conversely, the developed GSTEM-CAT tool was evaluated using a quantitative approach. A questionnaire was prepared which consisted of statements that were adapted from the ISO/IEC 9126. The respondents of the study were ninety three (93) Senior High School students. They were asked to respond to the statements in the survey questionnaire with regards to their level of acceptance towards the developed system in terms of functionality, usability and reliability. The proponents used the Likert Scale to address the measurement of the perception of the respondents about the developed system. Specifically, a five-point Likert Scale was used to measure the opinion of the respondents. It is a psychometric response scale often used in questionnaires and is the most widely used scale in survey research. When responding to a Likert questionnaire item, respondents specify their level of acceptance to a statement. The researchers used ranks from one to five: five being the highest and one being the lowest rank.

\section{THE DEVELOPED GSTEM CAT TOOL}

\section{A. System Architecture}

Fig. 1 depicts the system architecture of the developed tool. Initially, the developed mobile application gathers user's three preferred college program needed for the evaluation process. Then, it acquires input data using the GSTEM-CAT tool which is subdivided into two segments. The first segment is the personality test based on John Holland's code of career assessment which includes six primary types namely Realistic, Investigative, Artistic, Social, Enterprising and Conventional (RIASEC).

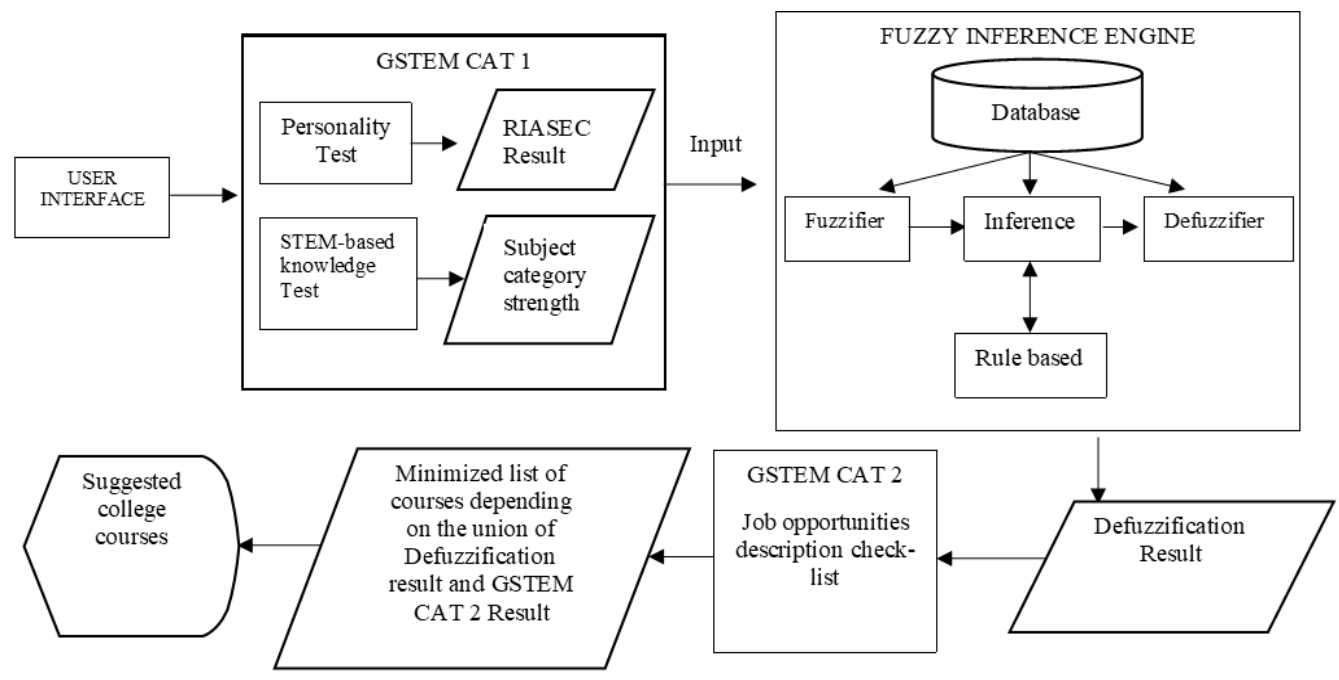

Fig.1. System architecture of the developed GSTEM CAT tool.

For further analysis and to maximize area of specializations, the researchers included the primary, secondary and tertiary combinations of RIASEC which are, 'RCAI', 'RAE', 'RIC', 'ISE', 'CSA', 'RA', 'SA', 'IA', 'I', ' $\mathrm{C}$ '. Each personality type is characterized by interests, preferred activities and abilities. In Holland's theory, each of these personality types can identify which job opportunities you belong to once you have taken a RIASEC test. For example, if your personality is extremely high in Realistic, possible careers for you are Agriculture, Anthropology, Carpentry, Chef and etc.

Using the list of possible job offers on each college course, the researchers itemized college programs on a decision table based from Holland's career code (see Table I).

To get the average percentage rating after the personality test, the researchers applied mean average formula multiplied to 100 which is defined in equation 1 :

$$
\bar{X}=\frac{\sum X}{n} \times 100
$$

where:

$\bar{X}$ : mean

$\sum X$ : summation of scores

$n$ : total number of items

The resulting answer will be the input for Personality Test in the fuzzy control model. 
TABLE I: DECISION TABLE BASED ON JOHN HOLLAND's CAREER CODE

\begin{tabular}{|c|c|c|}
\hline $\begin{array}{l}\text { Holland's } \\
\text { Code }\end{array}$ & $\begin{array}{l}\text { PUP College Programs } \\
\text { Recommended for } \\
\text { STEM }\end{array}$ & Possible Job Offers \\
\hline RAE & $\begin{array}{c}\text { Bachelor of Science in } \\
\text { Architecture (BS } \\
\text { ARCH) }\end{array}$ & $\begin{array}{l}\text { Building Contractor for } \\
\text { small scale projects } \\
\text { CADD Specialist } \\
\text { Architectural Designer } \\
\text { Inspector } \\
\text { Building Administration }\end{array}$ \\
\hline IA & $\begin{array}{l}\text { Bachelor of Science in } \\
\text { Mathematics (BSM) }\end{array}$ & Educator \\
\hline ISE & $\begin{array}{l}\text { Bachelor of Science in } \\
\text { Nutrition and Dietetics } \\
\text { (BSND) } \\
\text { Bachelor of Science in } \\
\text { Food Technology } \\
\text { (BSFT) }\end{array}$ & $\begin{array}{l}\text { Pharmacist } \\
\text { Nurse } \\
\text { Pediatrician } \\
\text { Nutritionist }\end{array}$ \\
\hline I & $\begin{array}{l}\text { Bachelor of Science in } \\
\text { Physics (BSP) } \\
\text { Bachelor of Science in } \\
\text { Biology (BSBIO) }\end{array}$ & $\begin{array}{l}\text { Educator } \\
\text { Scientist }\end{array}$ \\
\hline $\mathrm{C}$ & $\begin{array}{l}\text { Bachelor in Applied } \\
\text { Statistics (BAS) } \\
\text { Bachelor of Science in } \\
\text { Applied Mathematics } \\
\text { (BSAM) Major in } \\
\text { Actuarial Mathematics }\end{array}$ & $\begin{array}{l}\text { Educator } \\
\text { Administrator }\end{array}$ \\
\hline
\end{tabular}

The second segment of the tool is the STEM-based knowledge test. This aimed to know the strengths of the students in the specific subjects of the strand, namely Science, Technology, Engineering, and Mathematics (STEM's). The researchers evaluated and analyzed all college courses' curriculum to find out the student's area of focus among these core subjects. As a result, the authors assigned primary and combination of ' $S$ ', ' $T$ ', ' $E$ ', 'M' values into each of the courses.

The learning competencies data extracted from the Department of Education (DepEd) website's curriculum was evaluated by a knowledge expert. To get the average rating after the STEM-based knowledge test, the researchers used equation (1) to get the average percentage of the test result.

Now that the system produced two fuzzy sets which were both evaluated as \{weak, medium, good $\}$, it will now be directed to the crucial part of the fuzzy control model, the inference engine. The researchers used Fuzzy Associative Memory (FAM) to get the minimum (MIN) and intersection (AND) of the two fuzzy sets. This will result to the intersection of fuzzy values on each element of the RIASEC and fuzzy values on each element of STEM which will produce a lot of rules. The intersection between personality types and STEM-based knowledge is illustrated in the Table II.

Resulting rate from this test gives output knowledge strength rates in the STEMs areas. To identify college programs matching the subjects and personality types, the researchers gathered each course subjects' curriculum and identified which area need to focus. The system used a total of 630 rules in the inference engine.

Here is an example: IF personality is $\mathrm{C}(0.8)$ good and knowledge is $\mathrm{M}$ (0.9) good THEN the college courses suitable are Bachelor of Applied Statistics and Bachelor of Applied Math Major in Actuarial Mathematics.

To determine the best among the determined suitable tracks, the researchers used Max Membership Principle (also known as height method). This method is given by the algebraic expression:

$$
\mu_{\mathrm{C}}\left(z^{*}\right) \geq \mu_{\underset{\sim}{C}}(z) \quad \text { for all } z \in Z
$$

where $z^{*}$ is the defuzzified value, and is shown graphically in Fig. 2.

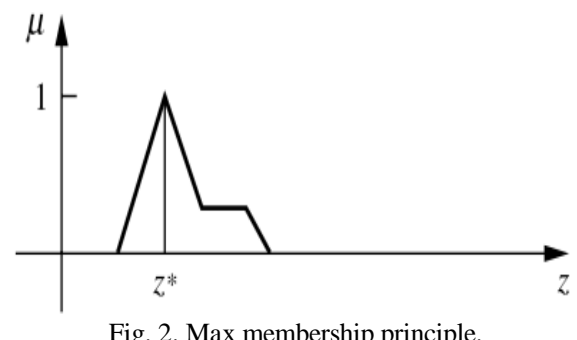

The defuzzified value still outputs various possible college courses. To further minimize the range, the defuzzified value will be processed in GSTEM-CAT II. From the possible job offers on each course on the defuzzifed value, the user will be selecting among the job descriptions checklist.

To get the result from the job descriptions checklist, the system will be outputting the corresponding course on the checked items.

The result from the GSTEM-CAT II or career test will be the final output of the system. Along with this, is the display of percentage rates in each of the personality and STEM-based knowledge elements.

TABLE II: FuZZY ASSOCIATIVE MEMORY (FAM) TABLE OF GSTEM-CAT

\begin{tabular}{|c|c|c|c|c|c|}
\hline Personality & Knowledge & $\begin{array}{l}\text { STEM } \\
\text { g m w }\end{array}$ & $\begin{array}{l}\text { STM } \\
\text { g m w }\end{array}$ & $\begin{array}{l}\text { TEM } \\
\text { g m w }\end{array}$ & $\begin{array}{l}\text { SM } \\
\text { g m w }\end{array}$ \\
\hline RCAI & $\begin{array}{l}\mathrm{g} \\
\mathrm{m} \\
\mathrm{W}\end{array}$ & \begin{tabular}{l}
\multicolumn{1}{c}{ BSCS } \\
BSIT \\
BSARCHI \\
BSCOE \\
BSME \\
BSCE \\
BSEE \\
BSIE \\
BSECE
\end{tabular} & $\begin{array}{l}\text { BSCS } \\
\text { BSIT } \\
\text { BSCH } \\
\text { EM } \\
\text { BSND } \\
\text { BSFT } \\
\text { BSP }\end{array}$ & $\begin{array}{l}\text { BSCS } \\
\text { BSIT } \\
\text { BSND }\end{array}$ & $\begin{array}{l}\text { BSCS } \\
\text { BSIT } \\
\text { BEED }\end{array}$ \\
\hline RAE & $\begin{array}{l}\mathrm{g} \\
\mathrm{m} \\
\mathrm{w}\end{array}$ & $\begin{array}{l}\text { BSCS } \\
\text { BSIT } \\
\text { BSARCHI } \\
\text { BSCOE } \\
\text { BSME } \\
\text { BSCE } \\
\text { BSEE } \\
\text { BSIE } \\
\text { BSECE }\end{array}$ & $\begin{array}{l}\text { BSCS } \\
\text { BSIT } \\
\text { BSCHE } \\
\text { M } \\
\text { BSND } \\
\text { BSFT } \\
\text { BSP }\end{array}$ & $\begin{array}{l}\text { BSCS } \\
\text { BSIT } \\
\text { BSND }\end{array}$ & $\begin{array}{l}\text { BSCS } \\
\text { BSIT } \\
\text { BEED }\end{array}$ \\
\hline CSA & $\begin{array}{l}\mathrm{g} \\
\mathrm{m} \\
\mathrm{w}\end{array}$ & $\begin{array}{l}\text { BSED } \\
\text { (MATH) } \\
\text { BSARCHI } \\
\text { BSCOE } \\
\text { BSME } \\
\text { BSCE } \\
\text { BSEE } \\
\text { BSIE } \\
\text { BSECE }\end{array}$ & $\begin{array}{l}\text { BSED } \\
\text { (MATH } \\
\text { ) } \\
\text { BSCHE } \\
\text { M } \\
\text { BSND } \\
\text { BSFT } \\
\text { BSP }\end{array}$ & $\begin{array}{l}\text { BSED } \\
\text { (MAT } \\
\text { H) } \\
\text { BSID } \\
\text { BSCS } \\
\text { BSIT }\end{array}$ & $\begin{array}{l}\text { BSED } \\
\text { (MAT } \\
\text { H) } \\
\text { BEED }\end{array}$ \\
\hline
\end{tabular}

And for the final segment of the assessment, the list of job opportunities in each course are extracted from the university website under academic colleges pages. All the knowledge that is necessary and available are extracted and embedded to 
the system as initial data.

\section{B. Features of the Developed GSTEM - CAT}

The GSTEM - CAT tool was developed using Android Studio IDE with Java as the programming language during the coding and testing phase. Firebase Real-time Database was used for handling inputted data sets, and storage for all the data records.

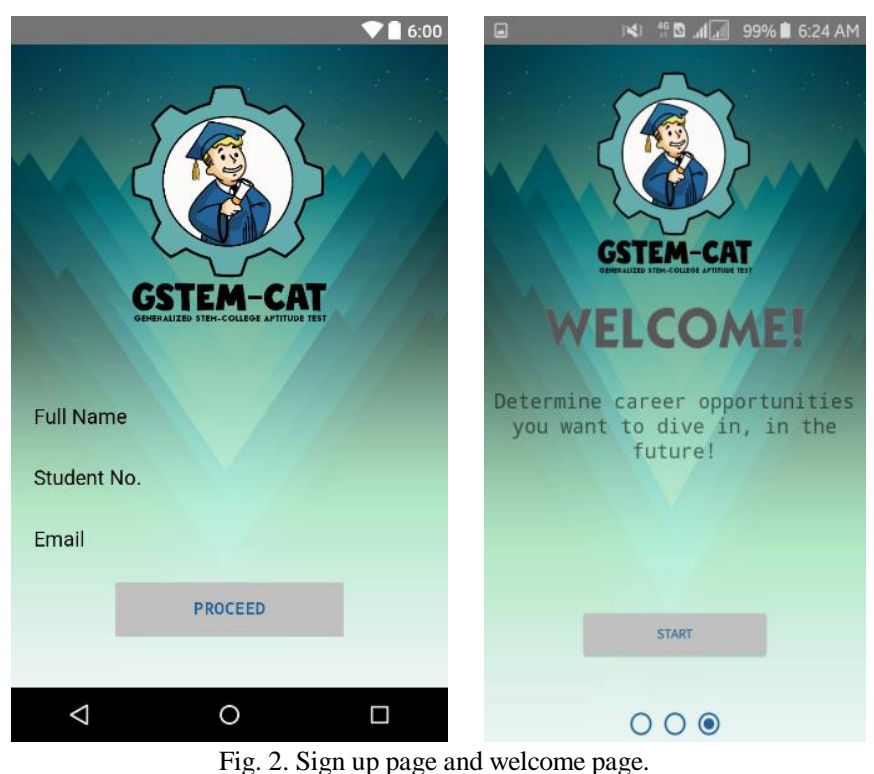

If the user clicks on "Get Started" button, (see Fig. 2) the user will be directed to the registration page followed by the welcome page. This page includes a brief description of the application. In every start of each segment, there is a pop-up help text for instructions. Personality Test Module (see Fig. 3) the students need to select image/s that corresponds to their personality. Meanwhile, if the user click Next button, the student will be directed to the Knowledge Strength Test (see Fig. 4) wherein the users shall rate their understanding in each topics using the Seek Bar.

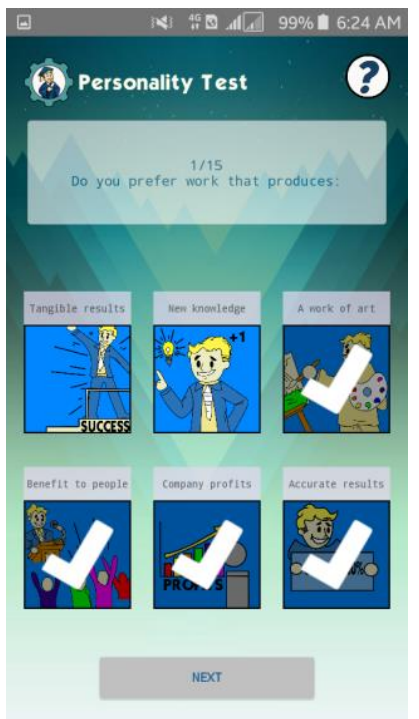

Fig. 3. Personality test module.

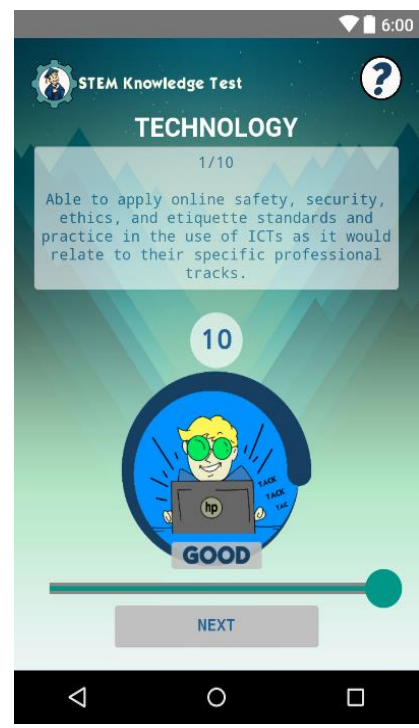

Fig. 4. Knowledge strength test.
Fig. 5 described the Career Selection Module. Students shall choose 5 career descriptions that they want to pursue in the future to further filter the suggested programs. On the other hand, in Fig. 6 students can see their personality type, knowledge strength, and the college course/s suitable for them. It also includes the percentage of belongingness of the students in the specific set of available program.

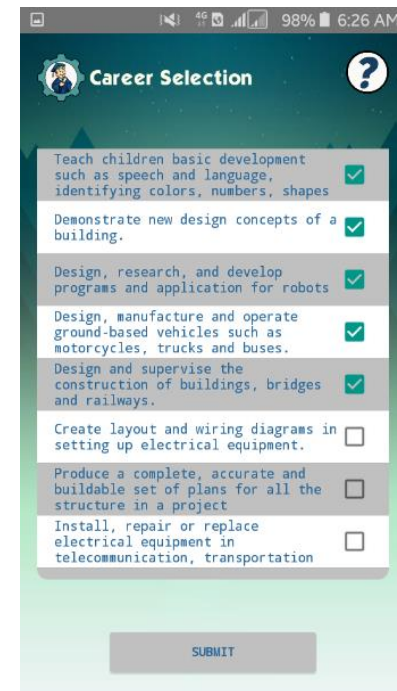

Fig. 5. Career selection module.

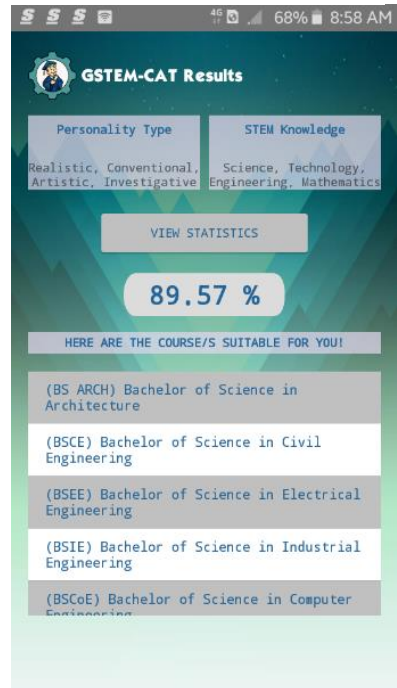

Fig. 6. Generation of report.

\section{EVALUATION AND RESULTS}

\section{A. The Challenges Encountered by the Respondents in Choosing Their College Program}

The data that was obtained from the survey questionnaires on 93 respondents answered the research problems established by the researchers. The researchers inquired for the challenges encountered by the respondents in selecting college programs. The analysis showed that $66 \%$ of the respondents tend to seek for existing applications that might help them decide their choice of college course. Aside from that, the researchers found out that most of them tend to focus on a single college course without looking up for other potential programs that they might fit in $(65 \%)$ and some considered the fact that their knowledge strengths and personality types might affect the list of programs they have considered taking $(63 \%)$.

\section{B. Appropriate Features of the Software that Can Be} Developed to Address the Challenges Encountered

To address all the challenges encountered by the respondents, the researchers manage to design, create and integrate appropriate features in the developed GSTEM-CAT tool in order to utilize and address the said difficulties. The developed application answers most of the challenges encountered by the respondents such as, "There is no existing software that can help the students to meet their decision-making in choosing college course/s" and "It is still complicated for the students to pursue college because they are still undecided of what course they should take." Specifically, the main segments of the developed tool such as listing up of initially preferred programs, the personality test, STEM-based knowledge test, and job descriptions checklist answer the respondents' difficulties in evaluating the courses 
they have considered taking.

The assessment report that can be generated from the application upon completion of the profile was able to aid the student in suggesting college courses suitable with the user's personality and knowledge strengths. The report also displays programs overview and statistical data of the user's results. In addition, the said software can display overview descriptions on its course, easing the student's unawareness and improving the decision-making process.

\section{The Level of Acceptance of the Respondents with the Developed Tool}

The respondents evaluated the developed tool in terms of functionality, usability and reliability. The researchers used Likert Scale to determine the level of acceptance of the respondents to the parameters established.

Table III described the summary of respondents' level of acceptance in terms of functionality. It illustrates that the evaluation of the students on the functionality of the developed software which implies that $87.4 \%$ of the respondents agreed that they already studied the topics on the STEM related scale type questions embedded in the developed application. However, item no.2 was highly accepted by the respondents which indicates that the system effectively assessed their personality and knowledge strengths. With item no.5 having the lowest mean of 3.99 , this implies that $79.8 \%$ of the respondents moderately accepted that the suggestions of the developed tool helped them reassure their decisions in selecting courses to take up in college. Overall, the students evaluated the developed system and rated their level of acceptance with a mean of 4.15 which implies that the functionality of the tool in suggesting suitable college courses based on their personality and knowledge strength garnered an average rating of $83 \%$.

Table IV described the summary of respondents' level of acceptance in terms of usability. As for the developed system's usability, it implies that the respondents are satisfied with the efficiency of the application, agreeing that the information as well as the presentation of the application is highly effective.

TABLE III: RESULTS OF FUNCTIONALITY EVALUATION

\begin{tabular}{|c|c|c|}
\hline Statements & Mean & $\begin{array}{l}\text { Verbal } \\
\text { Interpretation }\end{array}$ \\
\hline $\begin{array}{l}\text { The system provided STEM-related } \\
\text { questions on the test which the students' } \\
\text { have already studied. }\end{array}$ & 4.37 & $\begin{array}{l}\text { Highly } \\
\text { Acceptable }\end{array}$ \\
\hline $\begin{array}{l}\text { The system effectively assessed students' } \\
\text { personality and knowledge strengths }\end{array}$ & 4.20 & $\begin{array}{l}\text { Highly } \\
\text { Acceptable }\end{array}$ \\
\hline $\begin{array}{l}\text { The system has increased students' } \\
\text { awareness in taking a more suitable set of } \\
\text { college courses. }\end{array}$ & 4.15 & $\begin{array}{l}\text { Moderately } \\
\text { Acceptable }\end{array}$ \\
\hline $\begin{array}{l}\text { The tool successfully determined suitable } \\
\text { college courses for the students letting them } \\
\text { know where they fit best based on their } \\
\text { personality and STEM knowledge. }\end{array}$ & 4.03 & $\begin{array}{l}\text { Moderately } \\
\text { Acceptable }\end{array}$ \\
\hline $\begin{array}{l}\text { The tool developed reassured and helped } \\
\text { students to meet the decision-making need } \\
\text { in choosing college courses. }\end{array}$ & 3.99 & $\begin{array}{l}\text { Moderately } \\
\text { Acceptable }\end{array}$ \\
\hline OVER ALL MEAN & 4.15 & $\begin{array}{l}\text { Moderately } \\
\text { Acceptable }\end{array}$ \\
\hline
\end{tabular}

However, the respondents assessed that the system's functions and capabilities can be further improved as the tally shows that the frequency for the level of acceptance is almost evenly distributed which means that $78.2 \%$ of the students agreed that the system has all the features they needed. Nevertheless, the general implication of the results shows that the respondents are satisfied with the interface and how easy it is to use. To sum it up, the usability for the developed system is highly accepted by the respondents having a rating of $86.2 \%$.

TABLE IV: RESULTS OF USABILITY EVALUATION

\begin{tabular}{|c|c|c|}
\hline Statements & Mean & $\begin{array}{l}\text { Verbal } \\
\text { Interpretation }\end{array}$ \\
\hline \multirow{10}{*}{$\begin{array}{l}\text { The information provided with this system } \\
\text { such as on-screen help messages was clear. } \\
\text { Students would imagine that most people } \\
\text { would learn to use this system very quickly. } \\
\text { The information was effective in helping } \\
\text { students complete the tasks and scenarios. } \\
\text { Students were satisfied with the interface } \\
\text { and how easy it is to use the system. } \\
\text { The system has all the functions and } \\
\text { capabilities students expect it to have. }\end{array}$} & 4.55 & \multirow{11}{*}{$\begin{array}{l}\text { Highly } \\
\text { Acceptable } \\
\text { Highly } \\
\text { Acceptable } \\
\text { Highly } \\
\text { Acceptable } \\
\text { Highly } \\
\text { Acceptable } \\
\text { Moderately } \\
\text { Acceptable } \\
\text { Highly }\end{array}$} \\
\hline & 4.55 & \\
\hline & & \\
\hline & 4.43 & \\
\hline & & \\
\hline & 4.34 & \\
\hline & & \\
\hline & 4.30 & \\
\hline & 391 & \\
\hline & 3.91 & \\
\hline OVERALL MEAN & 4.31 & \\
\hline
\end{tabular}

Table V described the summary of respondents' level of acceptance in terms of reliability.

TABLE V: RESULTS OF RELIABILITY EVALUATION

\begin{tabular}{lcl}
\hline \multicolumn{1}{c}{ Statements } & Mean & $\begin{array}{l}\text { Verbal } \\
\text { Interpretation }\end{array}$ \\
\hline $\begin{array}{l}\text { On events of system crashing, students } \\
\text { manage to get back to the unfinished } \\
\text { session. }\end{array}$ & 4.71 & $\begin{array}{l}\text { Highly } \\
\text { Acceptable }\end{array}$ \\
$\begin{array}{l}\text { Students encountered no lags while using } \\
\text { the mobile-based application. }\end{array}$ & 4.20 & $\begin{array}{l}\text { Highly } \\
\text { Acceptable } \\
\text { While using the system, students } \\
\text { encountered zero errors and bugs. }\end{array}$ \\
$\begin{array}{l}\text { The tool run smooth and efficient with no } \\
\text { faults and errors. } \\
\text { The system gave error messages that clearly } \\
\text { told students how to fix problems. }\end{array}$ & 3.95 & $\begin{array}{l}\text { Moderately } \\
\text { Acceptable } \\
\text { Ooderately }\end{array}$ \\
OVERAL MEAN & $\mathbf{3 . 8 2}$ & $\begin{array}{l}\text { Acceptable } \\
\text { Moderately } \\
\text { Acceptable } \\
\text { Moderately } \\
\text { Acceptable }\end{array}$ \\
\hline \hline
\end{tabular}

The data for determining the level of respondents' acceptance in the reliability parameter of the developed tool shows that there are still room for improvements in the system's efficiency. With 2 out 5 being highly accepted, this implies that somehow, the respondents still managed to use the application efficiently. This indicates that $79 \%$ of the respondents have no troubles encountered while using the tool. The table shows that the mean for these items are low implying that the system somehow lacked on handling errors, but still, the ratings are considered as moderately accepted.

The level of acceptance in the reliability of the developed system as the researchers interpreted the data garnered a 4.10 mean which indicates that $82 \%$ of the students only moderately accepted the system's reliability.

Table VI described the overall summary of respondents' level of acceptance in terms of functionality, usability and reliability. The system garnered the highest mean of 4.31 in terms of usability which implies that $86.2 \%$ of the respondents highly accepted the developed system's usability. On the other hand, the functionality and the reliability 
parameters were both moderately accepted by the respondents. Functionality garnered an $83 \%$ level acceptance with a mean of 4.15 while the reliability got the lowest mean of 4.10 . This means that only $82 \%$ of the respondents agreed that the system's reliability is Moderately Accepted. Overall, the developed system got a grand mean of 4.19 which implies that $83.8 \%$ of the respondents Moderately accepted and agreed that the developed system is functional, usable and reliable.

TABLE VI: OVERALL SUMMARY OF RESPONDENTS' LEVEL OF ACCEPTANCE OF THE DEVELOPED SYSTEM

\begin{tabular}{lcl}
\hline \hline \multicolumn{1}{c}{ Parameters } & Mean & Verbal Interpretation \\
\hline Functionality & 4.15 & Moderately Acceptable \\
Usability & 4.31 & Highly Acceptable \\
Functionality & 4.15 & Moderately Acceptable \\
Usability & 4.31 & Highly Acceptable \\
Grand Mean & 4.19 & Moderately Acceptable \\
\hline \hline
\end{tabular}

\section{CONCLUSION AND RECOMMENDATION}

Based on the findings from the study, the researchers conclude that: 1.) The study, determined that the most encountered challenge by the respondents in choosing a college course is that there is no existing software that can help students in choosing a college course; 2.) The developed tool addressed the challenges encountered by the respondents and is significant in choosing the suitable course for them; 3 .) The results of the study showed that the parameters (functionality, usability, and reliability) that determines the efficiency of the application developed received a moderately acceptable rating which means that the topic can be further improved and can serve as a good research subject in the future.

The researchers would like to recommend the following: 1.) the university should implement the developed tool to wider users; 2.) The features of the system may be further improved by considering other factors other than personality and knowledge strengths that may affect the set of suitable college programs for the students and should define new test items that will absolutely improve the process in determining the knowledge rate of the students.

In the future, the researchers, will extend the study in recommending suitable college programs and include different strands from other tracks which includes: (a) Academic Track such as Accountancy, Business and Management (ABM), Humanities, and Social Sciences (HUMSS), General Academic Strand (GAS); (b) Sports Track; (c) Arts and Design Track; (d) Technical, Vocational, Livelihood (TVL) Home Economics (HE), Information and Communications Technology (ICT), Agri-Fishery Arts, Industrial Arts. Additionally, creating a web-based database administrator for easy utilization of student records will be an advantageous feature for the system. Furthermore, shifting the database of the developed system from Firebase to SQL will be helpful, as SQL provides more efficient data handling and querying.

\section{CONFLICT OF INTEREST}

The authors declare no conflict of interest.

\section{AUTHOR CONTRIBUTIONS}

The authors would like to thank the Polytechnic University of the Philippines for funding the presentation and publication of this research. We also thank the Faculty Members and Students who participated in the study by using the Generalized STEM-College Aptitude Test (GSTEM-CAT) tool that we have designed and developed.

B. E. V. Comendador was the over-all in-charge of the methods, design and functionalities needed for the prototype and its evaluation.

W.F.C. Becbec was in-charge in the review of related literature, data collection, design of the tool, analysis of the data collected, and coordinating with respondents.

J. R. P. de Guzman was in-charge of the development and testing of the prototype.

\section{REFERENCES}

[1] Department of Education, Republic of the Philippines (2013). [Online]. Available: https://www.deped.gov.ph/k-to-12/about/faq/

[2] 5 Reasons Why the STEM Strand Rocks. [Online]. Available: https://blog.edukasyon.ph/senior-high-school/5-reasons-stem-strand-rock $\mathrm{s} /$

[3] S. Thaker and V. Nagori. (2013). Critical evaluation of decision support system implemented for career selection and comparative analysis with expert system. [Online]. Available: http://www.academia.edu/30686332/Critical_Evaluation_of_Decision_ Support_System_Implemented_For_Career_Selection_and_Comparativ e_Analysis_with_Expert_System

[4] J. B. Caluza, "Predicting teachers' ICT competence in a philippine university using J48 algorithm," Indian Journal of Science and Technology, vol. 11, no. 7, February 2018.

[5] J. Vasquez and B. E. Comendador, "Competency Discovery system: Integrating the enhanced ID3 decision tree algorithm to predict the assessment competency of senior high school students," International Journal on Advanced Science, Engineering and Information Technology, vol. 9, no. 1, 2019.

[6] J. P. O. D. Rosa, "Experiences, perceptions and attitudes on ICT integration: A case study among novice and experienced language teachers in the Philippines," International Journal of Education and Development using Information and Communication Technology, vol. 12, issue 3, pp. 37-57, 2016.

[7] K. Ahmad, (2013). Fuzzy Logic and Fuzzy Systems - Properties \& Relationships. [Online]. Available: https://www.scss.tcd.ie/Khursid.Ahmad/Teaching/Lectures_on_Fuzzy_ Logic/CS4001_FuzzySets_Systems_Properties_Lect_2.pdf

[8] A. Mundra, A. S. Sunil, K. Sharma, P. Kumar, and D. Chauhan, "Decision support system for determining: right education career choice," in Proc. the International Conference on Communication Networks, 2014.

[9] N. Namlı and O. Senkal, "Using the fuzzy logic in assessing the programming performance of students," International Journal of Assessment Tools in Education, vol. 5, no. 4, pp. 701-712, 2018.

[10] G. Agarwa, S. Gupta, and A. Agrawa, "Evaluation of student performance for future perspective in terms of higher studies using fuzzy logic approach," International Journal of Computer Applications, pp. 0975-8887, vol. 181, no. 50, 2019.

[11] T. Razak, M. Hashim, N. Halim, and N. Shamsul, "Career path recommendation system for UiTM perlis students using fuzzy logic," in Proc. 5th International Conference on Intelligent and Advanced Systems, 2015.

[12] T. Feghali, I. Zbib, and S. Hallal, "A Web-based Decision Support Tool for Academic Advising," Educational Technology \& Society, vol. 14, no. 1, pp. 82-94, 2011.

Copyright (C) 2020 by the authors. This is an open access article distributed under the Creative Commons Attribution License which permits unrestricted use, distribution, and reproduction in any medium, provided the original work is properly cited (CC BY 4.0). 


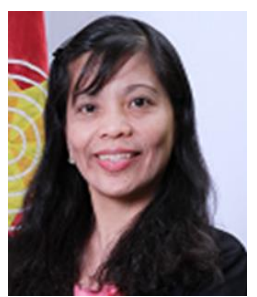

Benilda Eleonor V. Comendador earned her doctor in information technology (DIT) at the Technological Institute of the Philippines Quezon City in 2016. She was a grantee of the Japanese Grant Aid for Human Resource Development Scholarship (JDS) from April 2008 to September 2010.

She obtained the master of science in global information and telecommunication studies major in project research at Waseda University, Tokyo, Japan in 2010. She was commended for her exemplary performance in completing the said degree from JDS. She finished her master of science in information technology at Ateneo Information Technology Institute, Philippines in 2002. She is presently the academic program head of the Institute of the Open and Distance Education and concurrent program chair of the Master in Information Technology of the Graduate School of the Polytechnic University of the Philippines (PUP).

Her research interests include data mining, intelligent and knowledge based system, fuzzy control and system, ubiquitous computing, eLearning and related technologies and data security. She presented several research papers in various international conferences and published them in the international journals.

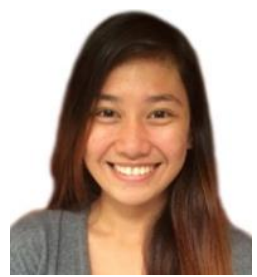

Wilmarie Faye C. Becbec was born in Pasay City, Metro Manila, Philippines on August 18, 1998. She earned a bachelor's degree in computer science in Polytechnic University of the Philippines, Sta. Mesa, Manila in May 2017. She is knowledgeable in C/C++, Java, C\#, HTML, CSS, JavaScript and PHP. Her research interests are intelligent and knowledge based system, fuzzy control and system, machine learning, digital game-based learning tool and mobile based applications and development.

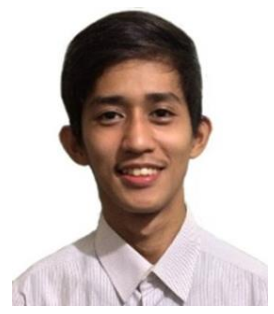

John Rez P. de Guzman was born in Pasig City, Metro Manila, Philippines on May 23, 1996. He is a graduate with the bachelor of science in computer science from Polytechnic University of the Philippines, Sta. Mesa, Manila. He is skilled in using object-oriented programming languages such as Java, Android and C\#. His research interests are intelligent and knowledge based system, fuzzy control and system, machine learning, digital game-based learning system, infographics and mobile based applications and development. 